J. Clin. Chem. Clin. Biochem:

Vol. 18, 1980, pp. 763-769

\title{
Present and Future Trends in Selected Areas of Clinical Enzymology ${ }^{1}$ )
}

\author{
By N.W. Tietz
}

University of Kentucky Medical Center, Department of Pathology, Lexington, $K Y, U . S . A$.

(Received February 15/May 28, 1980)

Summary: Recently developed enzyme tests that are used in (a) identifying high risk populations, (b) diagnosing cancer, (c) following treatment response of cancer patients, and (d) the selection of cancer therapy are summarized. The diagnostic role of methionine adenosyltransferase and CSF monoamine oxidase activity measurements in the diagnosis of schizophrenia are discussed. The role of $\mathrm{N}$-acetyltransferase in the conversion of serotonin to melatonin in the pineal gland and the importance of these changes for the synchronization of the functioning of cells throughout the organism are described. New developments in the determination of immunoreactive trypsin in the early diagnosis of pancreatic diseases are summarized.

\section{Gegenwärtige und zukünftige Trends in ausgewählten Gebieten der klinischen Enzymologie}

Zusammenfassung: Kürzlich entwickelte Enzym-Tests für (a) die Identifizierung von Risiko-Populationen, (b) die Diagnose von Carcinomen, (c) die Úberprüfung des Therapieerfolgs bei Carcinom-Patienten und (d) die Wahl der Carcinomtherapie werden zusammenfassend besprochen. Die diagnostische Bedeutung der Bestimmung der MethioninAdenosyltransferase und der Monoaminoxidase im Liquor für die Diagnose der Schizophrenie wird diskutiert. Die Rolle von N-Acetyltransferase im Stoffwechsel von Serotonin zu Melatonin in der Zirbeldrüse und dessen Bedeutung für die Synchronisation der Zellfunktion über den gesamten Organismus werden beschrieben. Neue Entwicklungen in der Bestimmung des immunreaktiven Trypsins zur Frühdiagnose von Pankreaserkrankungen werden zusammengefaßt.

\section{Introduction}

Some years ago, Albert Einstein stated, "Our time is distinguished by wonderful achievements in the field of scientific understanding and the applications of these insights."

This statement in its full import could be applied to the field of clinical enzymology, since there are few areas where developments have been so rapid, where the contributions to the understanding of the human organism have been so great, and where the benefits of scientific achievement to mankind have been as pronounced.

If we take a look at one of the charts depicting the pathways of intermediary metabolism of human cells, we can only be overwhelmed by the thousands of chemical reactions that are known today. Most of these reactions are catalyzed by enzymes, and over a thousand of these enzymes have so far been identified. There is evidence to believe, however, that many more enzymes remain to be

1) Keynote address given during the academic memorial services for Professor Dr. Gábor Szász held in conjunction with the Gabor Szzasz Symposium, Trends in Clinical Enzymology, November 9 and 10,1979, Giessen, Germany. discovered and that enzymes hold the key to the understanding of many normal body functions as well as pathological changes.

\section{The Role of Enzymes in Cancer}

The use of enzyme measurements in cancer goes back many years, but must still be viewed as an application that is just beginning to unfold. Enzymes have proven to be potentially useful as tumor markers in the early detection of cancer and metastases; in following progression of disease and response to treatment; in the detection of drug toxicity; and in the selection of the proper treatment of cancer if the diagnosis is once firmly established.

Much future effort must be expended to identify other enzymes and isoenzymes with greater sensitivity and specificity, with regard to pinpointing the site of a primary tumor or metastases. The search will extend from serum to other body fluids, such as urine, effusions, cysts and spinal fluid, as well as tissues and tissue scrapings. Efforts will be intensified to define high-risk populations and to improve our ability to determine treatment agents that are most likely to be of highest effectiveness. The search for suitable enzyme profiles and proper combinations of these with tests for tumor-associated antigens or 
other chemical tests will increase and strengthen our diagnostic and prognostic capabilities. Last, but not least, the study of enzymes will continue to be part of an overall investigation into the understanding of the malignant process as a whole.

A small selection of the most important, recent applications of enzyme tests are given below. Well established tests are not considered even though they may still have significant clinical usefulness.

Acid phosphatase in serum has been used in the detection of prostatic carcinoma for about 40 years. Unfortunately traditional spectrophotometric tests for the measurement of acid phosphatase detect about $90 \%$ of cases of prostatic cancer only after metastasis has taken place (1). However, recently developed immunochemical and radioimmunochemical techniques are said to be more sensitive and possibly more specific than former techniques.

The detection rates for prostatic cancer of Stages I, II, III, and IV, using the spectrophotometric enzyme methods were found to be $12,15,29$, and $62 \%$ (2), making these methods unsuitable for screening purposes. In contrast to this, Foti $(2,3)$ reported for the radioimmuno technique, a detection rate of $33,79,71$, and $92 \%$. Unfortunately, other studies have not shown such favorable results. New England Nuclear Laboratories give a detection rate of $8,21,40$, and $86 \%$, respectively, for their recently released product (4). Fleisher, in a personal communication, indicated a combined detection rate for Stage I and Stage II cancer of approximately $40 \%$. Differences in technique and production of antibodies as well as differences in the selection of the cut-off point are probable causes for these discrepancies.

There is a certain overlap of results obtained on patients with carcinoma of the prostate of Stages I and II on the one hand, and normals and patients with diseases other than prostatic cancer on the other hand. Above normal values were obtained in some patients with benign prostatic hypertrophy and in patients with other miscellaneous conditions. The exact percentage depends on the precise technique used and on the selection of the cutoff point $(1,2,5)$.

Most of the reported results have been observed on hospitalized populations suspected of having prostatic cancer, i.e. a population with a high prevalence for this cancer. If, however, the test is applied to a general population, the predictive value of this test is still relatively low (6). Aside from the low prevalence, this is due to the still relatively high rate of false positive results, i.e. the relatively low specificity of the test. Thus, it appears presently still doubtful that this technique is suitable as a screening procedure for the general population.

Efforts will undoubtedly continue to further refine this technique, to improve the standardization of the assay, and to compare this technique with counter-immunoelec trophoresis which is said to give fewer false positive re- sults $(5,7)$. Similar efforts to detect other organ specific enzymes by highly sensitive and specific techniques such as RIA and counter-immunoelectrophoresis can be expected. Suggestions that this be explored for breast and pancreatic cancer have already been advanced (8).

Increases in ribonuclease activity in serum were observed in a small number of patients with a variety of carcinomas, but mostly in pancreatic carcinoma. In one study, 28 of 30 patients had values two to seven times higher than the normal control group (9).

Sialyltransferase appears to be a very sensitive indicator for various forms of cancer, but especially of the colon and breast (10). In one study of 134 randomly selected patients with primary or metastatic cancer, 293 of 340 values were elevated (11). In a second study of $500 \mathrm{pa}$ tients, abnormal activity was found in $80 \%$ of cases. This compared with only $43 \%$ of elevated values for carcinoembryonic antigen (12). Sialyltransferase is also a useful indicator of treatment response. In 46 of 57 patients, the enzyme activity correlated well with the clinical course of the patients (11).

Galactosyltransferase isoenzyme II in serum has recently been claimed to be a sensitive marker for adenomas of various organs. Activity of this isoenzyme was increased between 44 and $100 \%$ of the cases, depending on the type of cancer (13) as shown in table 1.

In normal individuals, as well as in patients with nonmalignant disorders, no elevations of the isoenzyme II were found, except in alcoholic hepatitis and in celiac disease (13) (see tab. 2).

The degree of increase in enzyme activity correlates well with the progression of the disease (fig. 1). Sera from patients with colonic cancer, falling in Duke's classification A, had no significant elevations, while those in classifications B and C showed increasing levels of galactosyltransferase isoenzyme II. Highest levels were observed in pa-

Tab. 1. Galactosyltransferase II in malignant disorders (After Podolsky, (13), reprinted by permission).

\begin{tabular}{lrc}
\hline Name & $\begin{array}{c}\text { Sera } \\
\text { tested }\end{array}$ & $\begin{array}{c}\% \\
\text { Positive }\end{array}$ \\
\hline Colorectal Adenocarcinoma & 117 & 72.7 \\
Pancreatic Adenocarcinoma & 18 & 83.3 \\
Gastric Adenocarcinoma & 16 & 75.0 \\
Esophageal Squamous-Cell Carcinoma & 9 & 44.4 \\
Breast Adenocarcinoma & 23 & 78.3 \\
Bronchogenic Carcinoma & 20 & 65.0 \\
Unknown Primary Source & 4 & 75.0 \\
Gallbladder and Bile-Duct Carcinoma & 4 & 50.0 \\
Prostatic Carcinoma & 4 & $100: 0$ \\
Lymphoma (Hodgkin type) & 8 & $50: 0$ \\
Chronic Lymphocytic Leukemia & 2 & 100.0 \\
Melanoma & 2 & 0 \\
Osteosarcoma & 1 & 0 \\
Hepatoma & 2 & 100.0 \\
Renal Carcinoma & 2 & 50.0 \\
All Cancers & 232 & 71.1 \\
\hline
\end{tabular}


Tab. 2. Galactosyltransferase II in non-malignant disorders (After Podolsky, (13), reprinted by permission).

\begin{tabular}{lcc}
\hline Name & Sera tested & \% Positive \\
\hline Ulcerative Colitis & 12 & 0 \\
Crohn's Ileocolitis & 8 & 0 \\
Pancreatitis & 15 & 0 \\
Cholelithiasis & 4 & 0 \\
Biliary Cirrhosis & 2 & 0 \\
Alcoholic Hepatitis & 15 & 20.0 \\
Celiac Disease & 20 & 90.0 \\
\hline
\end{tabular}

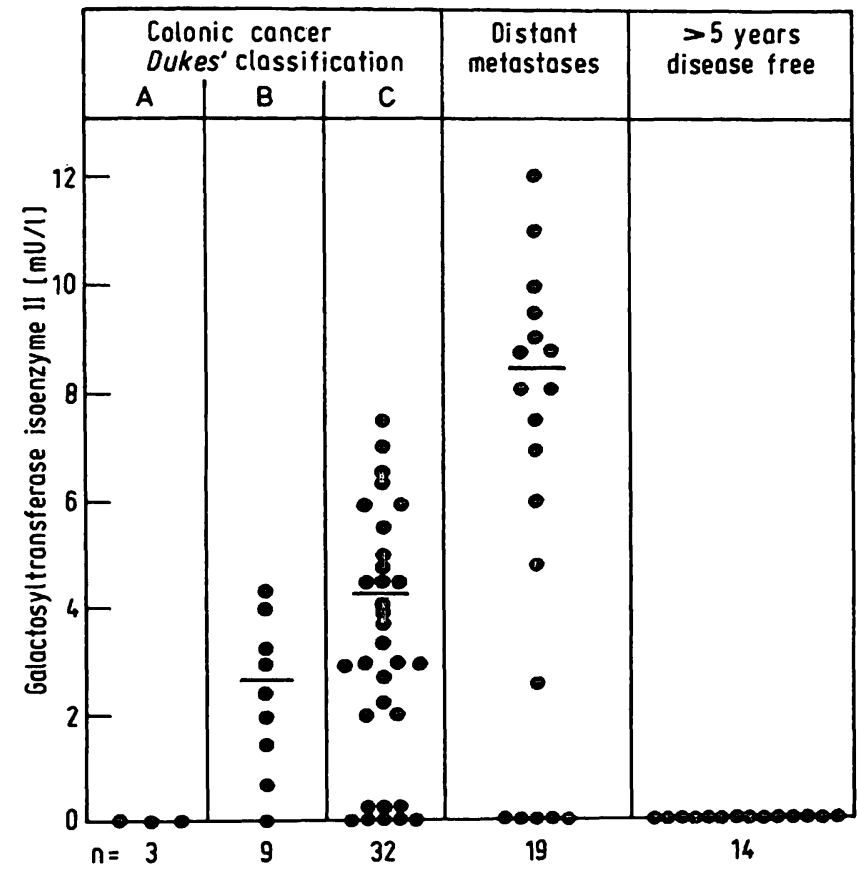

Fig. 1. Correlation of serum galactosyltransferase isoenzyme II levels with Duke's classification in colonic carcinoma (13). Modified reprint, by permission from the New England Journal of Medicine 299, 704 (1978).

tients with distant metastases. Patients who had undergone successful colectomy no longer showed increases in galactosyltransferase isoenzyme II activity (13).

UDP galactose: glycoprotein galactosyltransferase activity was found to be 3 to 5 times higher in ovarian tumor tissue than in normal tissue. Similar elevations were also seen in the serumm of patients with ovarian cancer (14).
Aryl-hydrocarbon hydroxylase is somewhat unique inasmuch as it can be induced by polycyclic aromatic hydrocarbons. These agents are hydroxylated by the enzyme to epoxides which then form covalent bonds with nucleic acids and proteins. Individuals in whom high enzyme activity is induced by exposure to these hydrocarbons appear to be especially susceptible to bronchiogenic carcinoma (15). Thus, this test is an example of the role of enzymes in the detection of high risk populations and the prevention of disease.

Recent work indicates that measurements of glycolytic enzymes (16) in breast tumor tissues are useful in the diagnosis of breast tumors; but, most of all, they are helpful in deciding the best course of treatment if breast carcinoma is once established. Here, it is more the enzyme pattern than the abnormality of any given enzyme which is of clinical usefulness.

Table 3 shows the activity of 6 glycolytic enzymes in non-carcinomatous and carcinomatous breast tissue. Phosphofructokinase, glucose-6-phosphate dehydrogenase, 6-phosphogluconate dehydrogenase, phosphoglucomutase, lactate dehydrogenase and phosphohexose isomerase all show significantly higher activities in cancer tissue as compared to benign mammary dysplasia or normal breast tissue (16).

These findings may have additional significance, since a different study showed that cancer associated with high levels of glycolytic enzymes responds better to chemotherapy than cases associated with low enzyme activity (17) (tab. 4).

Combining these findings with the experience obtained with the presence of estrogen receptor proteins and response to hormone therapy may give us a useful guide in the selection of therapy for breast cancer.

Presence of estrogen receptor proteins and a low enzyme profile suggest that hormone treatment will be most successful. Presence of estrogen receptor proteins and a high enzyme profile is an indication for hormone and chemotherapy. Absence of estrogen receptor proteins but presence of a high enzyme profile suggests chemotherapy. If both estrogen receptor proteins and the enzyme profile are low, no conclusions with regard to treatment can be drawn from these results (17).

Tab. 3. Mean enzyme catalytic activity content of human breast tissue (U/mg tissue). From: Deshpande, N., et al. (16).

\begin{tabular}{|c|c|c|c|c|}
\hline Enzyme & $\begin{array}{l}\text { Benign Mammary } \\
\text { Dysp̃lasiạ }\end{array}$ & I & III \& IV & Metastases \\
\hline $\begin{array}{l}\text { Phosphofructokinase } \\
\text { Glucose-6-phosphate dehy drogenạse } \\
\text { 6-phosphogluconate dehydrogenase } \\
\text { Phosphoglucomutase } \\
\text { Lactate dehydrogenase } \\
\text { Phôsphohexose isomerase }\end{array}$ & $\begin{array}{r}16 \\
36 \\
23 \\
358 \\
1068 \\
1525\end{array}$ & $\begin{array}{r}60^{*} \\
133^{*} \\
132^{*} \\
1327^{*} \\
6381^{*} \\
7421\end{array}$ & $\begin{array}{r}119 \\
226 \\
144 \\
1.383 \\
8.963 \\
10.903\end{array}$ & $\begin{array}{l}78 \\
252 \\
162 * * \\
1.802 \\
8.478 \\
10.233^{* *}\end{array}$ \\
\hline
\end{tabular}

\footnotetext{
* Significant difference between Benign Mammary Dysplasia \& Stage I Cancer
}

** Significant difference between Stage I \& Metastases 
Tab. 4. Mean enzyme cataly tic activity content of breast carcinomas of patients receiving chemotherapy $(\mathrm{U} / \mathrm{mg}$ DNA). From: Hilf, $R$., et al. (17).

\begin{tabular}{lrr}
\hline Enzyme & $\begin{array}{l}\text { Re- } \\
\text { sponders } \\
(17)\end{array}$ & $\begin{array}{l}\text { Nonre- } \\
\text { sponders } \\
(13)\end{array}$ \\
\hline Glucosephosphate isomerase & 21.31 & 6.69 \\
Lactate dehydrogenase & 16.12 & 8.94 \\
Isocitrate dehydrogenase & 1.05 & 0.45 \\
Pyruvate kinase & 16.08 & 11.55 \\
Glucose-6-phosphate dehydrogenase & 1.10 & 0.60 \\
6-phosphogluconate dehydrogenase & 0.68 & 0.35 \\
\hline
\end{tabular}

Tab. 5. Catechol-0-methyl transferase activity in human breast tissue. From: Assicot, M., et al. (18).

\begin{tabular}{llc}
\hline Tissue & & Activity* \\
\hline Normal Breast & $(32)$ & $344 \pm 83$ \\
Benign Tumor & $(18)$ & $570 \pm 155$ \\
Carcinoma & & \\
Grade I & $(13)$ & $555 \pm 152$ \\
Grade II & $(32)$ & $1538 \pm 328^{* *}$ \\
Grade III & $(33)$ & $1716 \pm 450^{* *}$ \\
\hline
\end{tabular}

* Expressed as pmoles of radioactive metanephrine formed per 20 min per mg of cy tosol protein.

** Significant compared with normal breast.

In general, tissue content of enzymes does not greatly differ with the stage of illness. The enzyme catechol-Omethyltransferase in breast tissue, however, is one of the exceptions where we have a progression in increase in values from normal breast tissue through Stages I, II, and III of cancer tissue (18) (tab. 5).

It is of particular interest that catechol-O-methyltransferase appears to be responsible for the 0-methylation of catechol-estrogens and might affect estrogen action on the tissues by acting as an anti-estrogen or inhibitor of estrogen binding to receptor proteins. This aspect should be the subject of further studies and could give us valuable information regarding predicted response to treatment.

Analysis of terminal deoxynucleotidyl transferase activity in lymphocytes has proven to be most useful in lymphoblastic disease for the confirmation of diagnosis, determination of the appropriate treatment, and for monitoring the response to treatment. The predicted response for therapy in some malignant lymphomas and leukemias is dependent on the cell phenotype; that is, whether the tumor is composed of T, B or "null" cells and whether or not the tissue is positive or negative for terminal deoxynucleotidyl transferase. For example, in childhood acute lymphocytic leukemia, the patient's favorable response to therapy can be predicted by the absence of T and B cell markers (i.e., presence of "null" cells) and the presence of terminal deoxynucleotidyl transferase activity. In chronic myelogenous leukemia, approximately $30 \%$ of those patients who enter "blast". crisis will have blast cells positive for terminal deoxynucleotidyl transferase and will respond to an acute lymphocytic leukemia-type therapy protocol. The remaining $70 \%$ will be negative for terminal deoxynucleotidyl transferase and will be resistant to all current forms of treatment (19).

Finally, I would like to point out two enzymes in spinal fluid which are helpful in demonstrating metastatic disease to the meninges. This is an especially important application, since such metastases --if detected in the early stage--respond to therapy in about $60 \%$ of cases (20).

The first enzyme is $\beta$-glucuronidase, which is present in normal spinal fluid at nearly $30 \mathrm{mU} / 1$. In meningeal carcinomatosis, significant increases in activity are observed. On the other hand, only a few cases of meningeal lymphoma with brain parenchymal metastases and with non-neoplastic mononuclear meningitis have values above the normal range (20). The presence of meningeal carcinomatosis can be further confirmed by measurement of the lactate dehydrogenase isoenzyme- 5 fraction, which is increased to above $10 \%$ in this disorder. In lymphomas or in leukemia, percentages of less than $10 \%$ are observed (20).

\section{Schizophrenia}

Another interesting development and area of predicted future activity is the elaboration of the causes for schizophrenia and the development of methods for the diagnosis of this disorder. Schizophrenia affects millions of individuals and its diagnosis is not only of interest for initiation of proper treatment but may also be of extreme importance for the determination of the guilt of a defendant during a trial.

Defects in transmethylation have long been suspected as a cause of schizophrenia, but it was not until recently that deficiencies in serine hydroxymethyl transferase and in the methionine-activating enzyme, methionine adenosyltransferase, have been demonstrated in blood (21). These deficiencies lead to a decrease in the production of S-adenosylmethionine, the high energy methyl donor.

Other investigations (22) have suggested that the platelet monoamine oxidase activity is reduced in chronic schizophrenics (fig. 2) and that its measurement may constitute a genetic marker for this disease.

Furthermore, there appears to be some evidence that the enzyme, monoamine oxidase, exists in two isoenzyme forms: type A and type B (23). The type A isoenzyme catalyzes predominantly the deamination of norepinephrine and serotonin, while dopamine is deaminated by both isoenzymes A and B (fig: 3 ). Experimental data seem to show that chronic schiziophrenia appears to be related to a type B deficiency, 


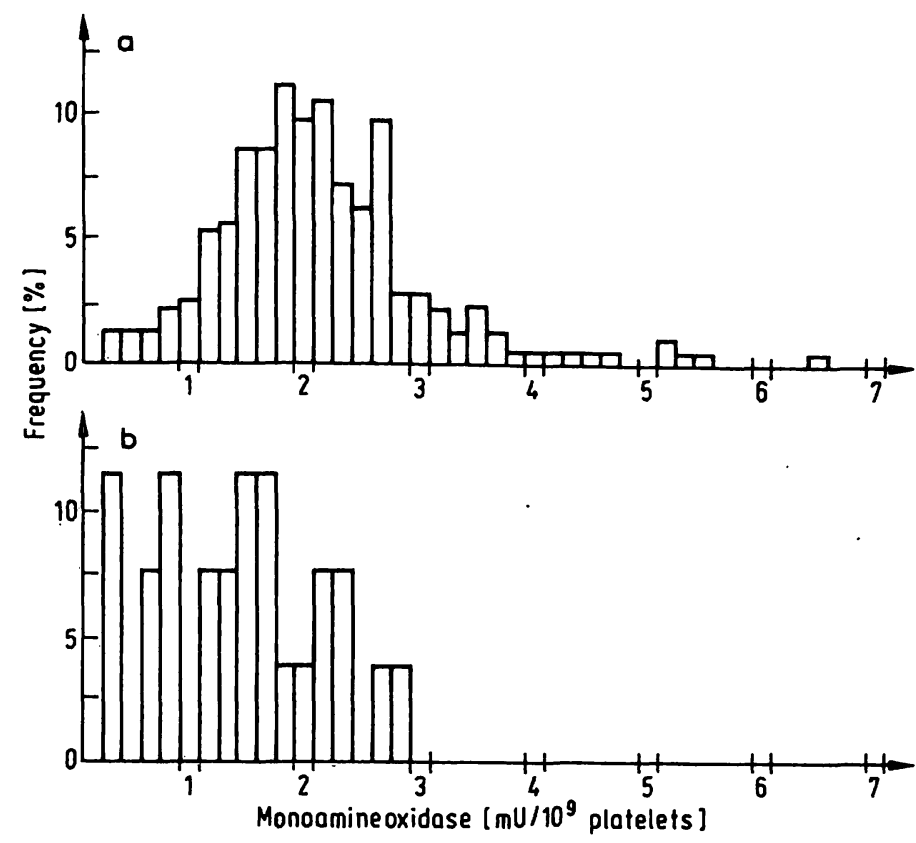

Fig. 2. Frequency distribution for platelet monoamine oxidase activity (substrate: benzylamine) in 332 female control subjects (a) and 26 female chronic schizophrenic patients (b) (22). Modified reprint, by permission from The American Journal of Psychiatry 136, 381 (1979).
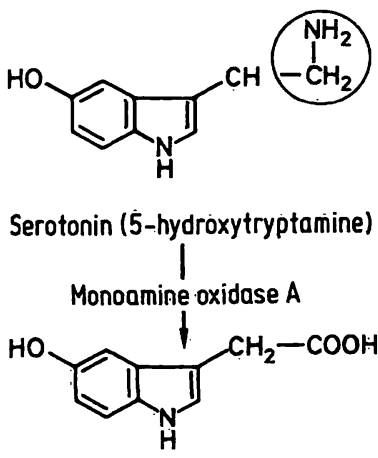

5-Hydroxyindoleacetic acid<smiles>NCCc1ccc(O)c(O)c1</smiles>

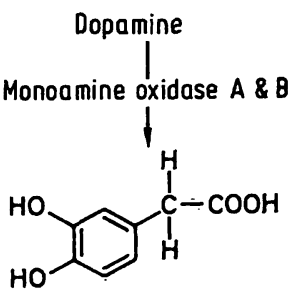

3.4-Dihydroxyphenylacetic acid<smiles>COc1cc(C(C)(C)C)ccc1O</smiles>

Homovanillic Acid

Fig. 3. Pathway of serotonin and dopamine metabolism. After: Tietz, N. W., ed., Fundamentals of Clinical Chemistry, W. B. Saunders, Philadelphia, 1976. Reproduced by permission from the publisher.

which is accompanied by a decreased spinal fluid concentration of homovanillic acid. On the other hand, low values of both 5-hydroxyindoleacetic acid and homovanillic acid in bipolar depressed patients suggests a deficiency of type A plus type B isoenzymes (23).

In addition to the quantitative differences, studies of the substrate specificity and the Michaelis-Menten constant suggest that the isoenzyme B in schizophrenics is different from that in normals.

While these findings do not show a causal relationship between these enzyme deficiencies and the development of schizophrenia, they seem to shed some light on a disease which has fascinated and puzzled scientists for many decades and indicate that further efforts could give us greater insights into the cause of this disease. Contradictory findings in the literature regarding enzyme activities in schizophrenia, may at least in part, be due to existing difficulties in classifying various forms of this disease.

\section{A Time-Keeping Enzyme in the Pineal Gland}

Let us now turn away from the diagnostic role of enzymes and take a look at the involvement of these catalysts in the mechanism of a biological clock--a system which senses and communicates time and thus regulates internal functions of an organism. Such a system has, indeed, been partially elaborated in a variety of vertebrate animals. These investigations have centered around the role of serotonin and its conversion into the hormone, melatonin.

Serotonin, in the presence of $\mathrm{N}$-acetyltransferase, is converted to $\mathrm{N}$-acetyl-serotonin, which is then converted to melatonin by the action of hydroxyindoleO-methyltransferase. It has been found that the activity of the melatonin synthesizing enzyme, hydroxyindole-Omethyltransferase, shows increases in activity during the night of $20 \%$ in chickens and increases up to $300 \%$ in some other animals (24).

This rhythm, however, is by far not as pronounced as the recently discovered circadian rhythm of $\mathrm{N}$-acetyltransferase, which shows peaks in the dark that are 27 to 70 times higher than the lowest value during the period of light (fig. 4). This increase parallels closely the production of melatonin (24). Through this mechanism, the pineal gland appears to function as a biological clock that is either controlled by or reset by light.

Corresponding to this circadian rhythm of enzyme activity, there is a change in serotonin and melatonin levels. Experiments on rats, for example, have shown that high levels of serotonin were found during the day (or light time), while low serotonin levels were found during the night (or dark time). Conversely, it was observed that the level of pineal melatonin was low during the day and high during the night. The low enzyme level during the day apparently reduces the conversion of serotonin to melatonin, while the high enzyme level during the night increases this conversion (24).

It is entirely possible that the enzyme, $\mathrm{N}$-acetyltransferase, by its periodic depletion of pineal stores of sero- 

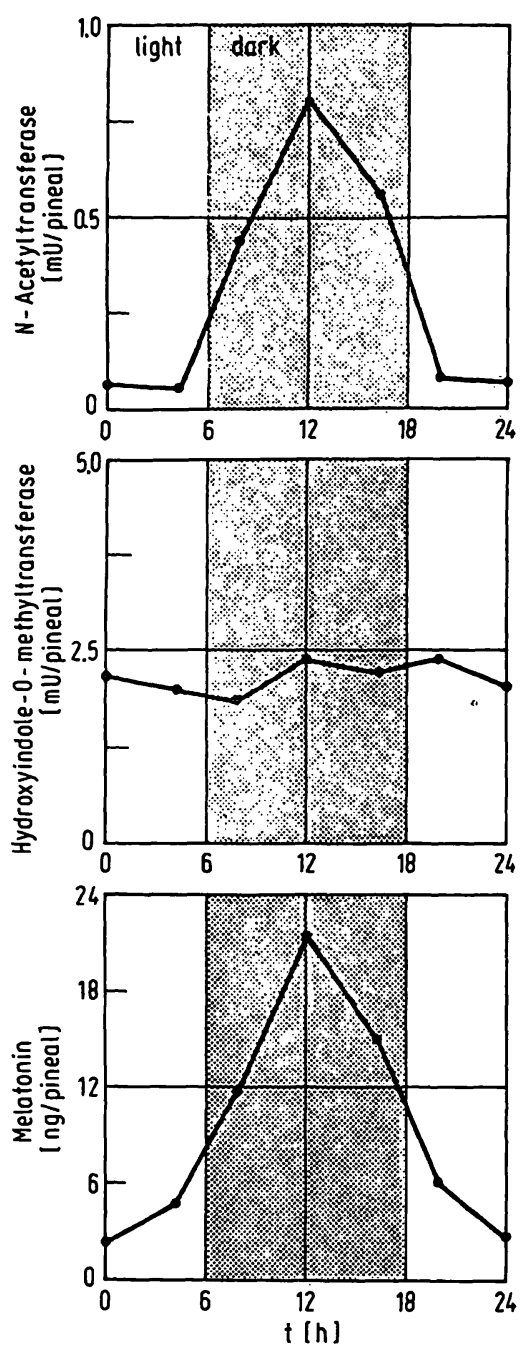

Fig. 4. Correlation of melatonin content and $\mathrm{N}$-acetyltransferase activity in the pineal gland during periods of light and darkness. Modified from Binkley, S., et al., Pineal Enzymes: Regulation of Avian Melatonin Synthesis. Science 181, 273 (1973). Copyright 1973 by the American Association for the Advancement of Science. Reproduced with permission.

tonin and production of melatonin from the gland, is involved in synchronizing the functioning of the cells throughout an entire organism. This hypothesis was strengthened by the sleep-inducing and temperaturelowering effect of melatonin, when injected into sparrows. Both of these effects are characteristic of the nighttime physiology in these birds (24).

At this time we have no precise knowledge of the mechanism by which the vertebrates sense the changes from light to dark, and there is strong evidence that the system just described is not the only biological clock of vertebrates.

\section{Immunoreactive Trypsin}

Pancreatitis is one of the first diseases in which an enzyme test was used to support a clinical diagnosis.
Amylase was initially found to be elevated in the urine and increases were subsequently confirmed in serum. Despite the extensive experience with this and other laboratory precedures, the diagnosis of pancreatitis remains a difficult one.

Recent efforts of several investigators have lead to a radioimmunochemical procedure which allows the determination of trypsinogen and trypsin in serum in the presence of its inhibitor, $\alpha_{1}$-antitrypsin. Preliminary reports indicate that immunoreactive trypsin is a highly sensitive and relatively specific indicator of pancreatic disease.

In the first reported study (25), all 8 cases of pancreatitis showed elevations in immunoreactive trypsin, varying from $150 \%$ to $4,000 \%$. One patient with parotitis with meningitis had normal immunoreactive trypsin activity, in spite of a significant elevation in plasma amylase.

In a second study (26), 2 patients with acute pancreatitis had 26 to 37 times the activity found in the control group. Values in peritoneal fluid of two patients with pancreatitis were 7 and 11 times the value of the control serum pool.

In a third study (27), all 14 patients with acute pancreatitis showed 3 to 30-fold increases in immunoreactive trypsin, compared with the control group. Immunoreactive trypsin levels in 11 of 16 patients with pancreatic cancer were also found to be abnormal, with 8 values being high and 3 values being low. In chronic pancreatitis, 15 of 23 patients showed abnormal values with 3 elevations and 12 values below the normal level (fig. 5). The different values observed in chronic pancreatitis and carcinoma of the pancreas are probably related to the amount of functioning pancreatic tissue and/or to the degree of obstruction.

At this point, it is difficult to fully evaluate the contribution which this test will make to the early diagnosis of pancreatic disease. This is partially due to the limited experience with the test, but also due to our inability to accurately identify patients with pancreatitis. Even invasive procedures cannot diagnose this disease with certainty. Early findings, however, seem to indicate that this test may have a greater sensitivity than presently available laboratory procedures, and its specificity also seems to be superior to the widely used amylase and lipase determinations in serum. The abnormal findings in chronic pancreatitis (and especially in carcinoma of the pancreas) may be a guide to the selection of further procedures to identify an early pathological process in the pancreas. In view of the fast growth rate and high death rate of cancer of the pancreas, a sensitive marker for the detection of early carcinoma is essential if treatment is to be successful.

This radioimmunochemical procedure for trypsin is just one of a number of similar tests which have found 


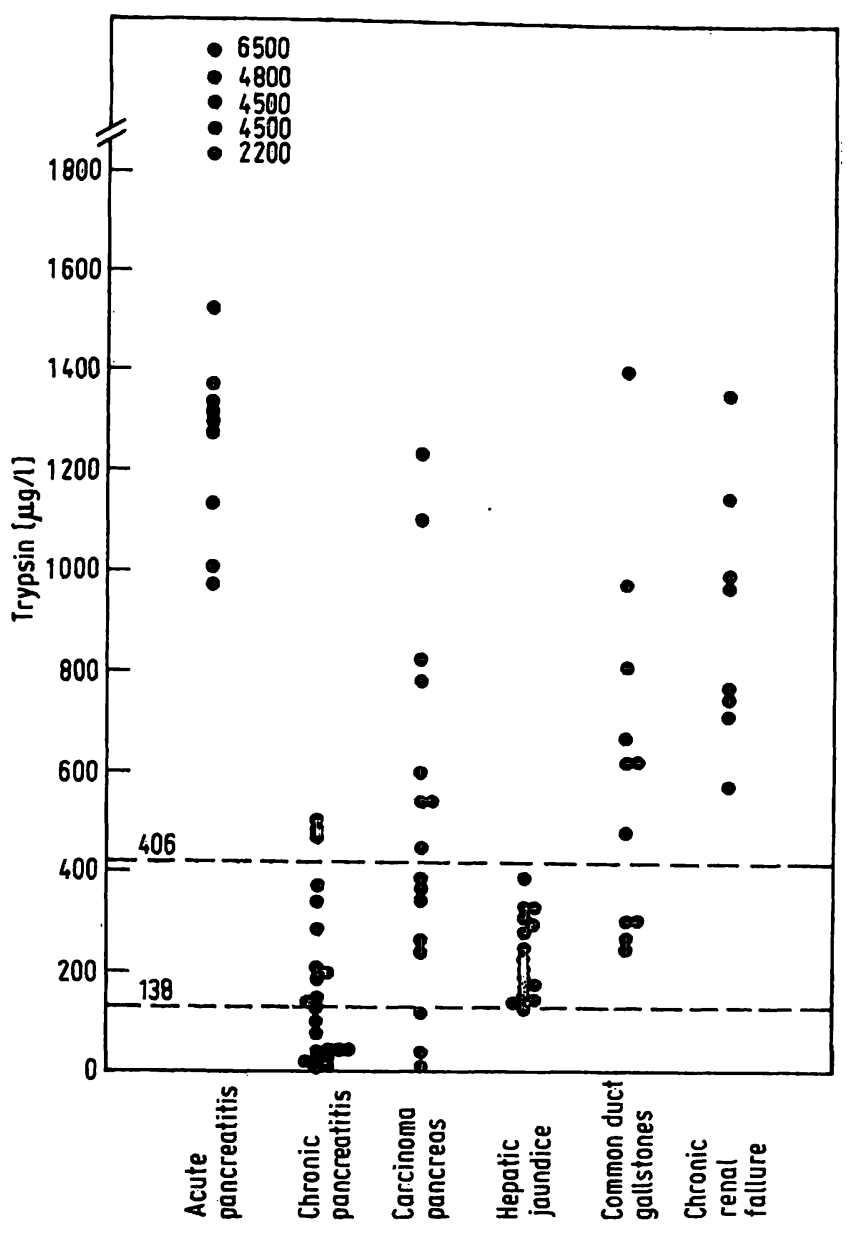

Fig. 5. Serum-trypsin concentrations in various pancreatic and other diseases. From: Elias, E. et al. Diagnostic importance of changes in circulating concentrations of immunoreactive trypsin. Lancet $I I, 67$ (1977). Reproduced by permission from the publisher. entry into the clinical laboratory. These tests are highly sensitive, they are potentially more specific than present procedures and they measure the actual amount of enzymes present as opposed to the activity. Thus, it can be expected that these procedures will be utilized in our clinical laboratory to an increasing extent. I do not anticipate, however, that radioimmunochemical tests will fully replace spectrophotometric procedures which are generally less expensive and offer greater convenience. In certain instances, where we are more interested in the enzyme activity than the amount of enzyme, use of these techniques indeed would be inappropriate.

\section{References}

1. Yam, L. T. (1974), Am. J. Med. 56, 604-616.

2. Foti, A. G., Cooper, J. F., Herschman, H. \& Malvaez, R. R. (1977), New Engl. J. Med. 297, 1357-1361.

3. Foti, A. G., Cooper, J. F., Herschman, H. \& Sapon, S. R. (1978), Hum. Pathol. 9, 618-620.

4. Prostatic acid phosphatase, clinical study of the Rianen TM prostatic acid phosphatase ${ }^{125}$ I RIA kit. (April 1979), New England Nuclear, Medical Diagnostics Division, North Billerica, MA 01862.

5. Schwartz, M. K. (1978), in Biological Markers of Neoplasia: Basic and Applied Aspects (Ruddon, ed.) Elsevier/North Holland, Inc., 503-515.

6. Carroll, B. J. (1978), New Engl. J. Med. 298, 912.

7. Romas, N. A. \& Tannenbaum, M. (1978), Hum. Pathol. 9, 620-621.

8. Bates, H. M. (1978), Lab. Management 16, 20-26.

9. Reddi, K. K. \& Holland, J. F. (1976), Proc. Natl. Açad. Sci. USA 73, 2308-2310.

10. Bosmann, H. B. \& Hall, T. C. (1974), Proc. Natl. Acad. Sci. USA 71, 1833-1837.

11. Henderson, M. \& Kessel, D. (1977), Cancer 39, 1129-1134.

12. Ganzinger, U. (1977), Wien. Klin. Wochenschr. 89, 594597.

13. Podolsky, D. K., Weiser, M. M., Isselbacher, K. J. \& Cohen, A. M. (1978), New Engl. J. Med. 299, 703-705.

14. Bhattacharya, M., Chatterjee, S. K. \& Barlow, J. J. (1976), Cancer Res. 36, 2096-2101.
15. Kellermann, G., Shaw, C. R. \& Luyten-Kellerman, M. (1973), New Engl. J. Med. 289, 934-937.

16. Deshpande, N., Mitchell, I. \& Millis, R. (1977), Europ. J. Cancer 13,1261-1267.

17. Hilf, R., Savlov, E. D., Rector, W. D. \& Wittliff, J. L. (1976), Cancer 38, 695-700.

18. Assicot, M., Contesso, G. \& Bohuon, C. (1977), Europ. J. Cancer 13, 961-966.

19. Coleman, M. S. \& Hutton, J., in The Leukemia Cell (D. Catovsky, ed.) Churchill Livingstone, Edinburgh, in press.

20. Fleisher, M., Schold, C., Schwartz, M. K. \& Posner, J. (1978), Clin. Chem. 24, 1002. Abstract.

21. Carl, G. F., Crews, E. L., Carmichael, S. M., Benesh, F. C. \& Smythies, J. R. (1978), Biol. Psychiatry 13, 773-776.

22. Wyatt, R. J., Potkin, S. G. \& Murphy, D. L. (1979), Am. J. Psychiatry 136, 377-385.

23. Bowers, M. B. (1976), Biol. Psychiatry 11, 245-249.

24. Binkley, S. (1973), Science 181, 273-275.

25. Temler, R. S. \& Felber, J. (1976), Biochim. Biophys. Acta 445, 720-728.

26. Borgström, A. \& Ohlsson, K. (1978), Hoppe-Seyler's Z. Physiol. Chem. 359, 677-681.

27. Elias, E., Wood, T. \& Redshaw, M. (1977), Lancet $I I, 66-$ 68.

Norbert W. Tietz, Ph. D. University of Kentucky Medical Center Department of Pathology Lexington, KY, 40536 USA 
